
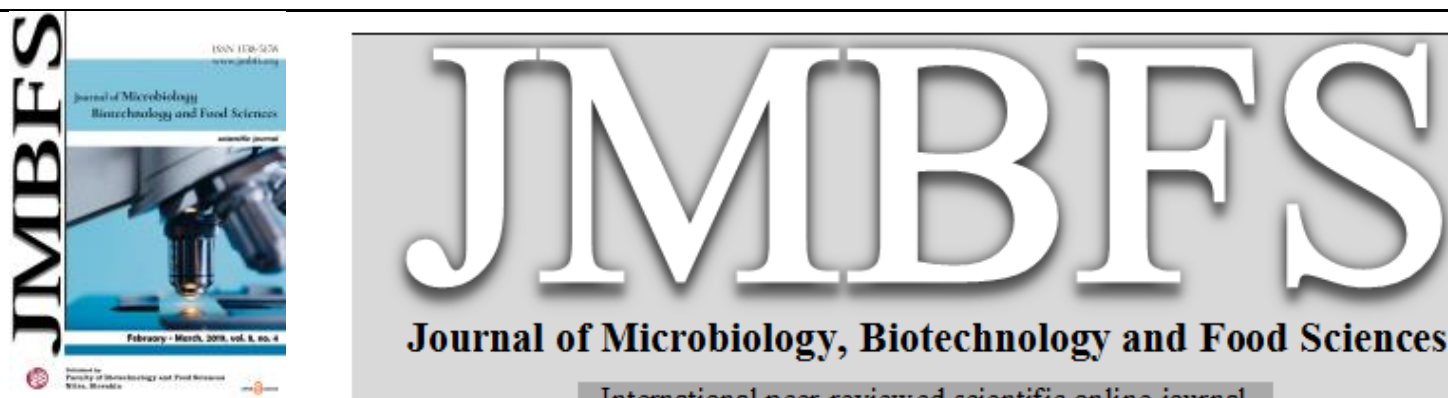

Journal of Microbiology, Biotechnology and Food Sciences

International peer-reviewed scientific online journal

\title{
ELIMINATION OF INFECTION PRESSURE OF THE BACTERIA PSEUDOMONAS TOLAASII DURING THE CULTIVATION OF PLEUROTUS OSTREATUS
}

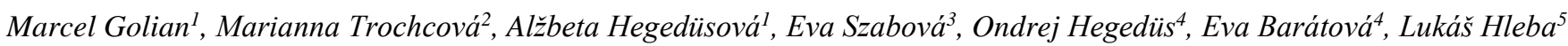

\section{Address(es):}

${ }^{1}$ Slovak University of Agriculture in Nitra, Horticulture and Landscape Engineering Faculty, Department of Vegetables Production, Tr. Andreja Hlinku 2, 94976 Nitra, Slovak Republic.

${ }^{2}$ Slovak University of Agriculture in Nitra,Faculty of Biotechnology and Food Sciences, Department of Biochemistry and Biotechnology, Tr. Andreja Hlinku 2, 94976 Nitra, Slovak Republic.

${ }^{3}$ Central Control and Testing Institute in Agriculture in Bratislava, Department of General and Quarantine Diagnostics, Matúškova 21, 83316 Bratislava, Slovak Republic.

${ }^{4}$ Regional Public Health Authority Nitra, Štefánikova trieda 58, 94901 Nitra, Slovak Republic.

${ }^{5}$ Slovak University of Agriculture in Nitra, Faculty of Biotechnology and Food Sciences, Department of Microbiology, Tr. Andreja Hlinku 2, 94976 Nitra, Slovak Republic.

*Corresponding author: marcel.golian1@gmail.com

doi: $10.15414 /$ jmbfs.2019.8.4.1080-1083

\section{ARTICLE INFO}

Received 17. 8. 2018

Revised 25. 10. 2018

Accepted 30. 10. 2018

Published 1. 2. 2019

Regular article

open ACCESS

\section{ABSTRACT}

Pleurotus spp. is in the top three of the most widely grown mushroom in the world's production. In connection with its intensive production in a conventional way, the risk of contamination with the most pathogens is avoided. The work deals with identification of the pathogen on the production crop of oyster mushroom, and with determining the optimal dilution of the commercially available disinfectant with $47 \mathrm{~g} / \mathrm{kg}$ (4.7\%) sodium hypochlorite to eliminate it. We found that the lethal dose of sodium hypochlorite for pathogen Pseudomonas tolaasii and for Pleurotus ostreatus is different, so we recommend using the disinfectant in specified dilutions even during the cultivation of oyster mushroom.

Keywords: Pleurotus ostreatus, disease, protection, Pseudomonas, chlorine

\section{INTRODUCTION}

Oyster mushroom was first scientifically described in 1775 by Dutch naturalist, Nikolaus Joseph Freiherr von Jacquin (1727 - 1817), under the name Agaricus ostreatus. Oyster mushroom is a fungus with variable size, shape and colour. There is a lot of strains in the world, therefore the identification of this species is relatively difficult. Oyster mushroom occurs mainly in European forests, where it is completely autochthonous.Production period is from end of the summer, through the autumn till the winter, if conditions are ideal. These edible fungi can sometimes be found through to cold months January and February.Oyster mushroom is a pleasant, slightly spicy mushroom (O'Reilly, 2011). In practicethere are most common cross-species and bredstrains of native species, which differ from wild strains mainly in thegrowth rate of fruiting bodies, yields, and other specific properties. For successful mass production, it is essential for the farmer himself to realize that oyster mushroom as it grows in situ on wood, above ground, in damp and light conditions, predominantly in deciduous forests (Kurtzman, 2014). Mishra and Tiwari (2012) reportedthat in addition to the concentration of $\mathrm{CO}_{2}$ in the production unit, light and relative humidity, the temperature affects the quantity and the quality of the produced mushrooms. During overgrowth of substrate by mycelium at the temperature $15{ }^{\circ} \mathrm{C}$ is growth linear. At temperatures in the range $20{ }^{\circ} \mathrm{C}$ to $30{ }^{\circ} \mathrm{C}$, the rate of overgrowth increase significantly. Intensive food production requires many measures related to hygiene of work, spaces and with production safety.

One of the most serious bacterial disease for oyster mushroom is Bacterial brown blotch disease, caused by the Gram-negative, naturally soil dwelling bacterium Pseudomonas tolaasii. Once the disease occurred in a farm, it was very difficult to control before all of the substrate bags were removed from the farm. The most typical symptom was characterized with brown spots or blotches on the pileus and stipes. If moisture conditions favoured the disease, the brown spots and blotches enlarge and coalesce with others; the affected areas are sunken and covered with sticky material. Rarely, the entire fruiting body is discolored with a reddish brown colour and appears water logged. Young fruiting bodies are covered by a clear, glossy material and cease to grow. However,it is still possible that mixed infections cause these various symptoms (Cha, 2004; MushWorld,
2004; Saxon et al., 2014; Zhang et al., 2013). The disease affected only the top external layers of the pileus tissuesand was restricted to $2-3 \mathrm{~mm}$ below the pileus surface. Brown discoloration results from mushroom production of melanin, which is a defence response induced in this case by $P$. tolaasii producing the toxin tolaasin. This extracellular toxin has been proved to be the major virulence factor (Saxon et al., 2014; Zhang et al., 2013). Tolaasin is a pore-forming toxin in the cell membranes, thus destroying the fruiting body structure of mushroom (Mu et al., 2015; Saxon et al., 2014). Pseudomonas tolaasii is also described as a pathogen of some plants (Cantore et al., 2015). Primary sources of Pseudomonas tolaasii on a mushroom farm were the peat and limestone used in the casing process. Secondary sources were numerous once the pathogen was present in mushroom beds. These included symptomless and diseased mushrooms, the fingers and shoes of people handling the crop, their baskets, knives and ladders. Spores of infected mushrooms may transport the bacterium, as did sciarid flies and mites which are common pests of mushroom crops (Wong and Preece,1980). The pathogen epiphytically colonized and grew on the vegetative mycelium in the substrate. During the development and growth of fruiting bodies, the pathogen reached and colonized the pileus, and infected the surface tissue. The disease has been difficult to control by spraying disinfectants or antibiotics onto fruiting bodies; it did not eradicate or reduce the inoculum in the spawned substrate contained in bags. Overhead watering may facilitate the growth and movement of the pathogen, and enlargement of the blotches (Wong and Preece, 1982; Zhang et al., 2013). Disease control on mushroom farms worldwide is commonly based on the use of fungicides. However, evolution of pathogen resistance to fungicides after frequent application, and host sensitivity to fungicides are serious problems. Only a few fungicides are officially recommended in mushroom production: chlorothalonil and thiabendazole in North America and prochloraz in the EU and some other countries. Calcium chloride and chlorinated compounds are, at the present time, the most commonly utilized chemicals for brown blotch disease control (Potočnik et al., 2015; Zhang et al. 2013). Treating $P$. tolaasii infection is difficult, as other, commensal bacterial species such as Pseudomonas putida are necessary for mushroom growth, so treatments must be relatively specific (Saxon et al., 2014) Biological control methods with antagonistic microorganisms and/or specific 
phages have also been investigated. However, none has been found fully effective so far (Zhang et al. 2013).

\section{MATERIAL AND METRHODS}

\section{Biological material}

Oyster mushroom strain KRYOS B was provided from Department of Horticulture, Faculty of Agrobiology, Food and Natural Resources, Czech University of Life Sciences Prague. This model strain is in mass production commonly used in present.

\section{Isolation and cultivation of bacteria}

Pathogenic bacteria were isolated from an infected production culture of oyster mushroom by sterile cotton swabs and transported to laboratory immediately. Bacterial isolates were spread on the surface of MPA (meat peptone agar) and cultivated at $20{ }^{\circ} \mathrm{C}$ for 48 hours. Grown cultures were purified by streak plate method. Pure cultures were used for further analysis.

\section{Identification of pathogen from fruiting bodies}

Pure colonies were transferred into the Eppendorf tube contained with $70 \%$ of ethanol. Colonies were homogenized and centrifuged at $10000 \mathrm{rpm}$ for $5 \mathrm{~min}$. Supernatant was removed. A $20 \mu 1$ of formic acid and $20 \mu 1$ of acetonitrile were added to pellet. Bacterial cells were homogenized and centrifuged at $10000 \mathrm{rpm}$ for 5 min. A $1 \mu \mathrm{l}$ of supernatant were transferred by pipetting into the MALDI TOF MS 96 Plate in 8 replicates. All samples were overlaid with HCCA matrix (Sigma Aldrich, Germany) dissolved in solution $(500 \mu \mathrm{l}$ of acetonitrile, $475 \mu \mathrm{l}$ of deionized water and $25 \mu \mathrm{l}$ of TFA - trifluoracetic acid) (Sigma Aldrich, Germany). After drying samples were identified by MALDI-TOF MS (Bruker Daltonics, Germany).

\section{Cultivation of pure cultures}

Pure cultures of both microorganisms were cultivated under sterile conditions on solid agar nutrient medium. For oyster mushroom production, PDA medium $(20 \mathrm{~g}$ glucose, $20 \mathrm{~g}$ agar powder, potato extract from $200 \mathrm{~g}$ potatoes, $1000 \mathrm{ml}$ water) was used. Pseudomonas tolaasii was cultivated on Meat peptoneagar no. 2 (MPA) The nutrient media were poured under aseptic conditions into sterile Petri dishes. Subsequently, they were inoculated with pure cultures of the microorganisms. Pleurotus ostreatus was inoculated with punctures using inoculating loop; Pseudomonas tolaasii was inoculated by spreading bacterial suspension onto a plateby glass spreader. Incubation was carried out in cultivatorsat $25^{\circ} \mathrm{C}$ in the dark until complete colonization of the agar surface by the microorganism.

\section{Dilution of solutions}

Testing of lethal dose disinfectant solution for microorganisms was ensured by the application commercially available disinfectant containingsodium hypochlorite $47 \mathrm{~g} / \mathrm{kg}(4.7 \%)$,in various concentrations of aqueous solution. The exact amount of concentrate was diluted with distilled water (dilution $0,3,5,8$, $10,15,20,25,30,35,40,50,60)$ and applied to pure cultures of both microorganisms.

\section{Application and evaluation}

Paper discs about $15 \mathrm{~mm}$ in diameter were wetted in the prepared solutions at the time of their preparation and immediately transferred to the bacterial and fungal culture. Three paper discs of the same concentration were placed in one Petri dish. Discs were removed after one day. Agar samples from the area under the discs were transferred to fresh agar plates, where their viability was monitored. Together, 12 variants were created, every variant had 3 repetitions and every repetition had 3 contact areas.

\section{Statistical processing methods}

Statgraphics Centurion XVII - multifactor analysis of variance (MANOVA, LSD test)

For detection of LD 50 and LD 90 Probit analysis was used.

\section{RESULTS AND DISCUSSION}

Isolated pathogen from production culture of oyster mushroom was identified on MALDI-TOF MS with using MaldiBiotyper identification software as Pseudomonas tolaasii. The authors mention, that the resistance of $P$. ostreatus may be the result of a serial of interactions between host and pathogen. The antagonistic action of vegetative mycelium to $P$. tolaasii may reduce the pathogen population in spawned substrate. However, the epiphytic populations of P. tolaasii for tested strains were not significantly different (Zhang et al., 2013)
There are various principles of eliminating pathogens. In terms of $P$. tolaasii, expect for chemical protection, biological protection based on antagonism of organisms is also being tested. It was found, thatapplication of bacteriophages is a very useful tool to decrease the density of pathogens and it has been successful to making disease-free cultivation area, known as phage therapy. Effect of phages on pathogen sterilization is very limited to the specific host strains. Minor variations of the host strains may cause changes in phage sensitivity (Park et al., 2016). Based on phenotypic, biochemical and molecular characteristics, the bacterial antagonists were identified as $P$. putida, $P$. reactants, $P$. fluorescens and Bacillus subtilis, respectively (Tajalipour et al., 2014). This statement confirms Bora and Özaktan (2000), who identified two strains of P. fluorescens and one strain $P$. putida, which resulted in a reduction of disease caused by $P$. tolaasii. Namazi et al. (2016) found, that Kocuria sp. being a promising candidate as a biological control agent against $P$. tolaasii. Bacteria strains Kocuria sp. and Pseudomonas spp., sprayed on freshly harvested mushroom caps, blocked the Bacterial Blotch incidence. Essential oil and extracts of some plants against this pathogenic bacterium have also been evaluated with promising results (Dezfooli et al., 2012). Saxon et al. 2014 tested Bdellovibrio as a possible biocontrol agent against $P$. tolaasii. They found out, that Bdellovibrio effectively suppressed the population growth of $P$. tolaasii, most likely due to killing by predation. Brown blotch lesion intensity was reduced by Bdellovibrio application onto mushrooms. Bdellovibrio application may therefore be more effective as a preventative measure to protect mushrooms against brown blotch disease, rather than a treatment for an already infected mushroom crop, and could be explored as a background addition to mushroom compost or casing layers to maintain "health". The economic impact of the disease is significant, resulting in loss of visual appeal to consumers and regular crop reductions. Since the use of financially costly preparations for the biological protection of $P$. ostreatus crops is not always possible, accurate agrotechnical practices and labor hygiene requirements should be respected in conventional production. Sanitation of premises before and between growing waves is a necessary operation. Disinfection before the storing of growing substrates is not a problem. It is most often carried out on the basis of the change of physical parameters (hot damp steam, UV light). It is also possible to disinfect with detergents suitable for use in the food production mainly floors, stands, knives, etc.

In this work we evaluated the resistance of $P$. tolaasii to the commercially available chlorine disinfectant containing sodium hypochlorite $47 \mathrm{~g} / \mathrm{kg}(4,7 \%)$ We found out that for the complete elimination of $P$. tolaasii, it is sufficient usedilution 0 to 25 (group a) of the concentrated chlorine-containing disinfectant with water. Dilution 30 to 60 (group b) was insufficient (Table 1, Picture 1).

Table 1 Inhibition of Pseudomonas tolaasii depending on dilution solution containing sodium hypochlorite according to Means and 95.0 Percent LDS Test \begin{tabular}{|c|c|c|c|c|c|c|c|c|}
\hline DILUTION & Count & Group & DILUTION & Count & Group & DILUTION & Count & Group \\
\hline
\end{tabular}

\begin{tabular}{|c|c|c|c|c|c|c|c|c|}
\hline DILUTION & Count & Group & DILUTION & Count & Group & DILUTION & Count & Group \\
\hline 0 & 4 & $\mathrm{a}$ & 15 & 4 & $\mathrm{a}$ & 35 & 4 & $\mathrm{~b}$ \\
\hline 3 & 4 & $\mathrm{a}$ & 20 & 4 & $\mathrm{a}$ & 40 & 4 & $\mathrm{~b}$ \\
\hline 8 & 4 & $\mathrm{a}$ & 25 & 4 & $\mathrm{a}$ & 50 & 4 & $\mathrm{~b}$ \\
\hline 10 & 4 & $\mathrm{a}$ & 30 & 4 & $\mathrm{~b}$ & 60 & 4 & $\mathrm{~b}$ \\
\hline
\end{tabular}

Legend: Values in columns with different letters are significantly different at $\mathrm{P}<0.05$ by LSD in ANOVA

Table 2 Inverse Predictions for concentration

\begin{tabular}{|l|c|c|c|c|}
\hline Percent & $\begin{array}{c}\text { Concentration } \\
\left(\mathrm{g} . \mathrm{L}^{-1}\right)\end{array}$ & Percent & $\begin{array}{c}\text { Concentration } \\
\left(\mathrm{g} . \mathrm{L}^{-I}\right)\end{array}$ \\
\hline 0.1 & 1.88262 & & 55.0 & 1.78522 \\
\hline 0.5 & 1.86704 & & 60.0 & 1.78135 \\
\hline 1.0 & 1.85949 & & 65.0 & 1.77736 \\
\hline 2.0 & 1.85123 & & 70.0 & 1.77314 \\
\hline 3.0 & 1.84599 & & 75.0 & 1.7686 \\
\hline 4.0 & 1.84205 & & 80.0 & 1.76354 \\
\hline 5.0 & 1.83885 & & 85.0 & 1.75764 \\
\hline 6.0 & 1.83612 & & 90.0 & 1.75021 \\
\hline 7.0 & 1.83373 & & 91.0 & 1.74842 \\
\hline 8.0 & 1.83158 & & 92.0 & 1.74647 \\
\hline 9.0 & 1.82964 & & 93.0 & 1.74433 \\
\hline 10.0 & 1.82784 & LD 90 & 94.0 & 1.74194 \\
\hline 15.0 & 1.82042 & & 95.0 & 1.73921 \\
\hline 20.0 & 1.81452 & & 96.0 & 1.736 \\
\hline 25.0 & 1.80946 & & 97.0 & 1.73206 \\
\hline 30.0 & 1.80491 & & 98.0 & 1.72682 \\
\hline 35.0 & 1.8007 & & 99.0 & 1.71857 \\
\hline 40.0 & 1.7967 & & 99.5 & 1.71101 \\
\hline 45.0 & 1.79283 & & 99.9 & 1.69543 \\
\hline 50.0 & 1.78903 & LD 50 & & \\
\hline
\end{tabular}

Legend: LD 50 - at this concentration $50 \%$ of microorganisms died; LD 90 - at this concentration $90 \%$ of microorganisms died. This model was successful at $100 \%$. 


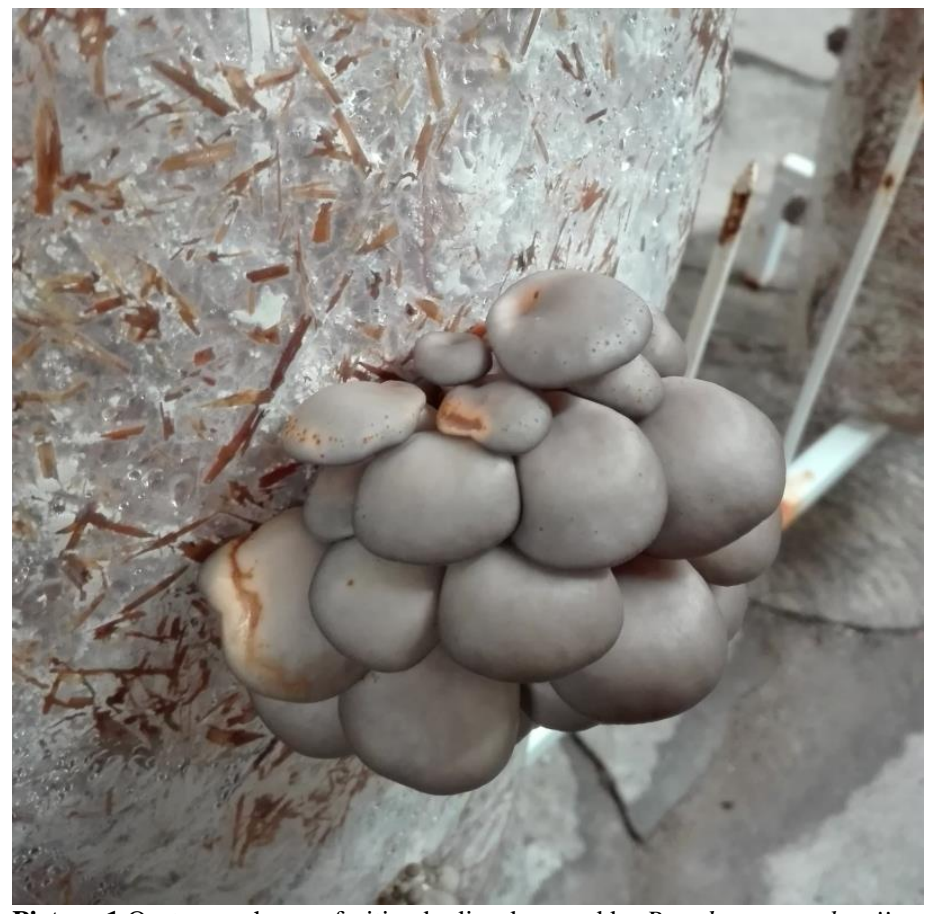

Picture 1 Oyster mushroom fruiting bodies damaged by Pseudomonas tolaasii

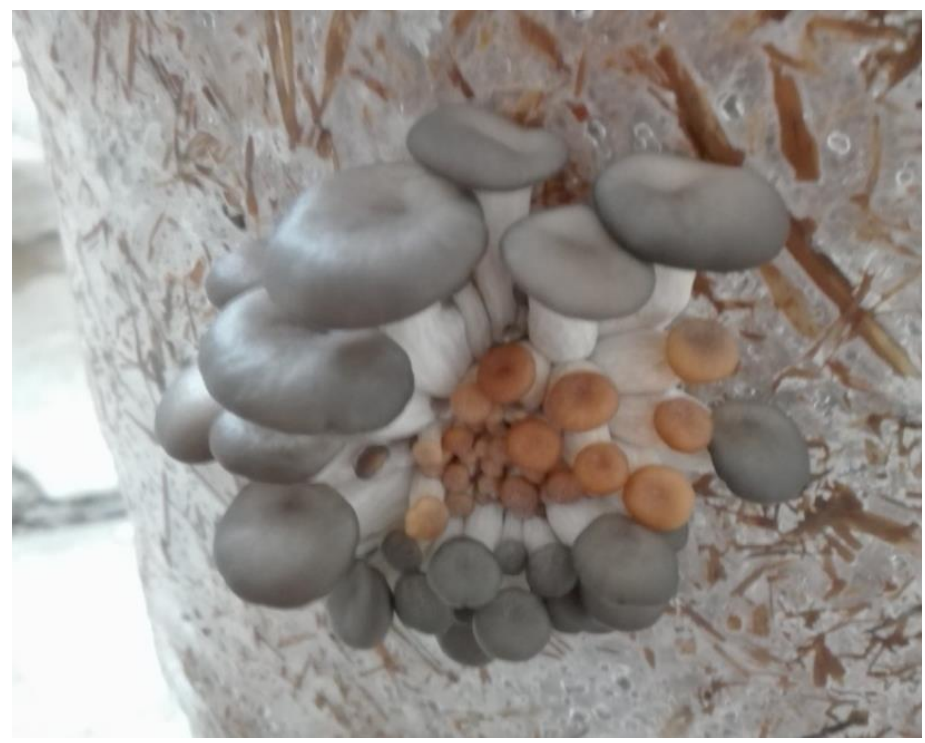

Picture 2 Oyster mushroom fruiting bodies damaged by Pseudomonas tolaasii

The problem arises when disinfecting a cultivation room between first and second flush, in the presence of substrates. We can confirm that the less concentrated sodium hypochlorite solution, the smaller dying of oyster mushroom mycelium. On the basis of the experiments, we found out that the lethal dilution for the test strain of oyster mushroom KRYOS B is dilution 10 (group a). Dilution 15 (group b) causes strong inhibition and dilution 20 and 25 (group bc) causes only a small inhibition in mycelial growth of Pleurotus ostreatus, and no oyster mushroom mycelium dying has been observed at dilution 30 (group c) (Table 3)

Table 3 Inhibition of Pleurotus ostreatus depending on dilution solution containing sodium hypochlorite according to Means and 95.0 Percent LDS Test. The values in the columns with different letters are significantly different from each other.

\begin{tabular}{|l|l|l|l|l|l|l|l|l|}
\hline DILUTION & Count & Group & DILUTION & Count & Group & DILUTION & Count & Group \\
\hline 5 & 9 & $\mathrm{a}$ & 15 & 9 & $\mathrm{~b}$ & 25 & 9 & $\mathrm{bc}$ \\
\hline 10 & 9 & $\mathrm{a}$ & 20 & 9 & $\mathrm{bc}$ & 30 & 9 & $\mathrm{c}$ \\
\hline
\end{tabular}

The current best methods of disease prevention are addition of chlorinated compounds such as calcium hypochlorite to irrigation water, and careful control of growth conditions; for example, the surface moisture of mushrooms and water level in the casing soil to minimize $P$. tolaasii chemotaxis and motility; however, the success of disease prevention is highly variable, and not guaranteed (Saxon et al. 2014). In any case, we do not recommend the application of the disinfectant solution directly during the growth of the fruiting bodies, since at the dilution of
30 there is a visible change in the colour of the fruiting bodies (loss of colour). The fruiting bodies are able to grow without difficulty, but the colour change makes them unsuitable for sale.

\section{CONCLUSION}

In this work was isolated and subsequently identified a serious pathogen Pseudomonas tolaasii, causing significant economic losses in the production of edible and medicinal fungus Pleurotus ostreatus. In the next step, dilution of disinfectant solution containing $47 \mathrm{~g} / \mathrm{kg}(4.7 \%)$ sodium hypochlorite intended for pathogen elimination was determined. Also, the maximum possibledilution of solution has been determined, which prevents losses of oyster mushroom cultures. With regard to the elimination of the $P$. tolaasii, we recommended disinfect the floors, walls and all equipment with authorized disinfectant containing $47 \mathrm{~g} / \mathrm{kg}(4.7 \%)$ sodium hypochlorite and dilution 25 before storing of the substrates in the production unit. Between individual flush waves, we recommend disinfecting surfaces of substrates and harvest points by the same concentration of sodium hypochlorite, without causing significant damage on oyster mushroom mycelium. In any case, we do not recommend the disinfection of the growing fruiting bodies, because just very little concentration of sodium hypochlorite causing decolourization of fruiting bodies.

Acknowledgement: The work was supported by VEGA project No. 1/0087/17.

\section{REFERENCES}

BORA, T. - ÖZAKTAN, H. 2000.Biological Control of Some Important Mushroom Diseases in Turkey by Fluorescent Pseudomonads.In Science and Cultivation of Edible Fungi.Proceedings of the 15th International Congress on the Science and Cultivation of Edible Fungi, Maastricht, Netherlands, pp. 689693. ISBN 9058091457.

CANTORE, P. L. - GIORGIO, A. - IACOBELLIS, N. S. 2015. Bioactivity of volatile organic compounds produced by Pseudomonas tolaasii.In Frontiers in Microbiology, vol. 6. DOI: 10.3389/fmicb.2015.01082

CHA, J.S. 2004.Pest and Disease Management.Oyster mushroom cultivation. Mushroom Grower's Handbook 1. 192-196.

DEZFOOLI, N. A. - HASANZADEH, N. - REZAEE, M. B. - GHASEMI, A 2012. Antibacterial activity and chemical compositions of Chamaemelumnobile essential oil/extracts against Pseudomonas tolaasii, the causative agent of mushroom brown blotch. In Annals of Biological Research, vol. 3, no. 6, pp. 2602-2608. ISSN 0976-1233.

KURTZMAN, R. 2014. El Porque y el comoen el cultivo del hongoostra: unaPerspectiva Mundial. Haciaundesarrollosostenible del sistema de producción: Avances y perspectivasen el Siglo. [online] 2014 [cit. 18.12.2017] online:

http://www cabdirect.org/abstracts/2

0113162462.html;jsessionid=BCD1FB845EC9AF78A3334D59DC34C38D,

ISBN 970-9752-01-4

MISHRA, S.K. - TIWARI, A.K. 2012. Pfenological, quantitative and analytical studies of Pleurotus.African Journal of Biotechnology, no. 11, pp. 346-354. ISSN 1684-5315.

MU, L. - YUN, Y. B. - PARK, S. J.- CHA, J. S. - KIM, Y. K. 2015. Various Pathogenic Pseudomonas Strains that Cause Brown Blotch Disease in Cultivated Mushrooms. In Journal of Applied Biological Chemistry, vol. 58, no. 4, pp. 349-354. ISSN 2234-7941, DOI: http://dx.doi.org/10.3839/jabc.2015.055.

MushWorld (Anonym), 2004. In Oyster Mushroom Cultivation, Mushroom Grower's Handbook 1

NAMAZI, Z. - HASANZADEH, N. - RAZMI, J. 2016. Kocuria sp. a potential antagonist of brown blotch caused by Pseudomonas tolaasii. In Journal of Biodiversity and Environmental Sciences (JBES), vol. 8, no. 1, pp. 159-166.ISSN 2222-3045 (Online).

O'REILLY, P. 2011.Fascinated by Fungi.In Fist Nature.[online] 2011. [cit. 18.12.2017].online: http://www.first-nature.com/fungi/pleurotus-ostreatus.php.

PARK, S. - HAN, J. - KIM, Y. K. 2016. Isolation of bacteriophage-resistan Pseudomonas tolaasii strains and their pathogenic characters.In Journal of Applied Biological Chemistry vol. 59, no. 4, pp. 351-356. ISSN 2234 7941,DOI:http://dx.doi.org/10.3839/jabc.2016.059.

POTOČNIK, I. - STEPANOVIĆ, M. - REKANOVIĆ, E. - TODOROVIĆ, B. MILIJAŠEVIĆ-MARČIĆ, S. 2015. Disease control by chemical and biological fungicides in cultivated mushrooms: button mushroom, oyster mushroom and shiitake. In Pesticides \&Phytomedicine (Belgrade), vol. 30, no. 4, pp. 201-208 ISSN 2406-1026.DOI: 10.2298/PIF1504201P.

SAXON, E. B. - JACKSON, R. W. - BHUMBRA, S. - SMITH, T. SOCKETT, R. E. 2014. Bdellovibriobacteriovorus HD100 guards against Pseudomonas tolaasiibrown-blotch lesions on the surface of post-harves Agaricusbisporus supermarket mushrooms. In BMC Microbiology, vol. 14 pp. 163. ISSN 1471-2180,DOI: https://doi.org/10.1186/1471-2180-14-163.

TAJALIPOUR, S. - HASSANZADEH, N. - JOLFAEE, H. K.- HEYDARI, A. GHASEMI, A. 2014. Biological control of mushroom brown blotch disease using antagonistic bacteria. In Biocontrol Science and Technology,vol. 24,no. 4, pp 
473-484.

ISSN

1360-0478,

DOI

http://dx.doi.org/10.1080/09583157.2013.873113.

WONG, W. C. - PREECE, T. F. 1980. Pseudomonas tolaasiin Mushroom Crops: A Note on Primary and Secondary Sources of the Bacterium on a Commercial Farm in England. In Journal of Applied Microbiology, vol. 49, no. 2, pp. 305314. ISSN 1365-2672, DOI: 10.1111/j.1365-2672.1980.tb05129.x.

WONG, W. C. - PREECE, T. F. 1982. Pseudomonas tolaasiiin cultivated mushroom Agaricusbisporus crops: numbers of the bacterium and symptom development on mushrooms grown in various environments after artificial inoculation. In Journal of Applied Microbiology, vol. 53, no. 1, pp. 87-96. ISSN 1365-2672, DOI: 10.1111/j.1365-2672.1982.tb04737.x.

ZHANG, R. Y. - HU, D. D. - GU, J. G. - ZUO, X. M. - HU, Q. X, - ZHANG, J.

X. 2013. Evaluation of oyster mushroom strains for resistance to Pseudomonas tolaasiiby inoculation in spawned substrates. In European Journal of Plant Pathology, vol. 137, no. 1, pp. 119-126. ISSN 0929-1873, DOI: 10.1007/s10658013-0223-6. 